\title{
Obesity and Its Risk Factors of among School Children in Sylhet, Bangladesh
}

\author{
Madhusudan Saha, ${ }^{1}$ Dipal Krishna Adhikary, ${ }^{2}$ Irin Parvin, ${ }^{3}$ Yuba Raj Sharma, ${ }^{4}$ Fahmida Akhter, ${ }^{5}$ Monojit \\ Majumder ${ }^{6}$ \\ 'Department of Gastroenterology, North East Medical College, Sylhet, ${ }^{2}$ Department of Cardiology, BSMMU \\ Dhaka, ${ }^{3}$ Department of Gastroenterology, Enam Medical College, Savar, Dhaka, ${ }^{4}$ Department of Internal \\ Medicine, Patan Academy of Health Sciences, Kathmandu, ${ }^{5}$ Department of Medicine, North East Medical \\ College, Sylhet, ${ }^{6}$ Department of Biochemistry, Sylhet M A G Osmani Medical College, Sylhet.
}

\section{ABSTRACT}

Background: Childhood obesity is found in affluent society, less physical activity and changes in food pattern. This study was designed to see prevalence and risk factors of childhood obesity among school children of Sylhet city.

Methods: Students of class five and six of two schools of Sylhet city were randomly selected. Demographic and anthropometric data were collected and recorded in predesigned data sheet. BMI and percentile were calculated using official centre for disease control growth chart for 2 to 20 years. Logistic regression analysis was done to see association of various factors with childhood obesity. P value of $\leq 0.05$ was taken as significant.

Results: Total 288 children were included in this study. Age varied from 10 to 14 years. Among them 5.6\% and 8.7\% were found to be obese and overweight respectively. Obesity was significantly higher among girls (6.8\% vs $3.6 \%)$. Prevalence of obesity and overweight $(\mathrm{p}=0.001)$ was more among those who spent less time in physical exercise and outdoor games. Food habit, television watching, computer gaming and duration of sleep were not found as significant predictor of obesity.

Conclusions: Obesity was significantly higher among girls $(6.8 \%$ vs3.6\%). Girls with less physical activity were mainly associated with overweight and obesity.

Keywords: Children; obesity; overweight; prevalence.

\section{INTRODUCTION}

Childhood obesity considered a metabolic derangement has become a global health problem and is associated with increased incidence of hypertension, diabetes, coronary artery disease and osteoarthritis and overall increases morbidity and mortality during adult life. ${ }^{1,2}$ One study revealed the prevalence $10.6 \%$, in high affluent countries and $5.2 \%$ in low-income countries. ${ }^{3-5}$ In Thailand, prevalence of childhood obesity has been found to be $10.8 \%$ in urban most wealthy region. ${ }^{6}$ In Pakistan, $6 \%$ obese and $8 \%$ overweight children were found and of all obese children, $70 \%$ belonged to higher socio-economic status group. ${ }^{7}$ In India, more than $22 \%$ obese school children belonged to higher socioeconomic status group. ${ }^{8}$ In one study from Dhaka, $17.9 \%$ were obese and $23.6 \%$ overweight school children and adolescents of affluent family. ${ }^{9}$ This study was designed to see prevalence, life style and associated risk factors of obesity and overweight among school children in Sylhet city.

DOI: http://dx.doi.org/10.3126/ inhrc.v16i2.20311
Correspondence: Dr Yuba Raj Sharma, Patan Academy of Health Sciences, Patan Hospital, Lalitpur, Nepal. Email: dryubarajsharmapi@gmail.com, Phone: +9779851125566.

\section{METHODS}

This cross sectional study was performed in September 2014. Data were collected from two Bengali medium schools of Sylhet city. Prior permission and consent were taken from school authorities. Children were selected from class five and six by random sampling according to class roll number. Socio-demographic, anthropometric data, food habit and life style data were recorded in a predesigned data sheet. Children suffering from chronic illness and unable to answer the predesigned questionnaire were excluded. Body mass (BMI) was calculated. Digital weighing machine and vertical scale were used to measure these parameters. Date of birth of children was collected from school registry book. Percentile was calculated using Official Centre for Disease Control (CDC) growth chart for boys and girls age 2 to 20 years. ${ }^{10}$ Subsets with BMI 95 or above percentile were taken as obese. $\mathrm{BMI}$ of $85^{\text {th }}$ to $94^{\text {th }}$ percentile were taken as overweight. Children with BMI from 5th to $84^{\text {th }}$ 
percentile were considered as normal and BMI less than $5^{\text {th }}$ percentile were taken as under-weight.

Sample size was calculated using formula $n=Z^{2} \cdot p \cdot q / d^{2}$ ( $n=$ sample size, $Z=1.96$ at $95 \%$ confidence limit, $p=20 \%$ - assumed proportion having particular characteristic [overweight and obesity], $q=1-p, d=$ degree of accuracy desired [15-25\%, i.e. 5 percentage points]). ${ }^{11}$ For $P=$ 0.20 and $d=0.05$ a sample size of 246 and a total of 288 children were included. Chi square test was done during comparison of categorical variables. Multiple logistic regression was done totest association of various factors with childhood obesity and overweight. $P$ value $\leq 0.05$ was taken as significant level. Ethical clearance was obtained from the Institutional research committee.

\section{RESULTS}

Total 288 children; boys 112 (38.89\%) and girls 176 (61.11\%), age ranging from 10 years to 14 years (mean 11.43 , SD 1.003) wereincluded in this study. Height of children varied from $120 \mathrm{~cm}$ to $175 \mathrm{~cm}$ (mean 143.83, $\mathrm{SD}=9.649$ ) and weight of them varied from $18 \mathrm{~kg}$ to 74 $\mathrm{kg}$ (mean 36.93, SD=9.903) (Table 1). Age of boys varied from 10-14 years (mean 11.78, SD 1.37) while girls from 10-14 (11.43, SD 0.837). Height of boys varied from 120 $\mathrm{cm}$ to $175 \mathrm{~cm}$ (mean 142.58, SD 10.45) and that of girls varied from $123 \mathrm{~cm}$ to $167 \mathrm{~cm}$ (mean 144.62, SD 8.97). Weight of boys varied from 18-61 kg (mean 35.07, SD 8.99 ) and that of girls varied from $21-74 \mathrm{~kg}$ (mean 38.12 , SD 10.29) (Table 1).

In this series total, $25(8.68 \%)$ and $16(5.55 \%)$ were found to be overweight and obese respectively. And 52 (18.05\%) were found to be underweight. Of all girls, 16 (9.09\%) and $12(6.82 \%)$ were overweight and obese respectively. Among all boys 9 (8.03\%) and 4 (3.57\%) were overweight and obese respectively (Table 2 ). Obesity and overweight were significantly more among girls $(P=0.017)$.

Fifteen (10.0\%) and 13 (9.22\%) children of middle class group were overweight and obese respectively. While 9 (17.65\%) and 2 (3.9\%) children belonging to rich family was overweight and obese respectively. This constituted $24 / 25$ (96\%) and 15/16 (93.7\%) of total overweight and obese children in this study and it is statistically significant $(P=0.000)$.

In this series, obesity and overweight prevalence was significantly lower (Table 2) among children's spending more than 60 min per day in physical exercise and outdoor games $(P=0.001)$.

Habit of fast food intake and television watching did not affect the prevalence of obesity and overweight. But $9(8.11 \%)$ children were found to be obese who were involved in video game, while only 7 (3.95\%) were obese among those whole did not take part in video game (Table 2) and the difference was significant.

To find out the associated factors for obesity logistic regression was done with sex, economic condition, physical activity, television watching, video game playing, computer game playing and sleeping duration.

\section{DISCUSSION}

The prevalence of obesity and overweight were $5.6 \%$ and $8.7 \%$ respectively in this study and the study included children from all the socio economic groups. It was seen lower than the report from Dhaka, ${ }^{9}$ which included children from affluent society only. However, obestiy was lower and overweight was higher in another study ${ }^{2}$ which included both urban and rural children. In addition, Sylhet has less urbanization and lesser economic transition than Dhaka. This study also revealed that prevalence of obesity and overweight was significantly higher among children belonging to middle class and higher socioeconomic group. In multivariate logistic regression analysis higher economic condition was found as an important predictor for obesity and overweight. This trend is similar but lower than other reports. ${ }^{7,9-12}$ But it is similar to that of Pakistan. ${ }^{7}$ In our study prevalence of obesity and overweight were significantly higher among girls $(P=0.017)$.

\begin{tabular}{|c|c|c|c|c|c|c|c|c|c|}
\hline & No (\%) & $\begin{array}{l}\text { Height } \\
\text { range } \mathrm{cm}\end{array}$ & Average & $\begin{array}{l}\text { Weight } \\
\text { range } \mathrm{Kg}\end{array}$ & Average & $\begin{array}{r}\text { Sleeping } \\
\text { hours }\end{array}$ & Average & $\begin{array}{c}\text { Age range } \\
\text { Yr. }\end{array}$ & Average \\
\hline Boys & $\begin{array}{r}112 \\
(38.89)\end{array}$ & $120-175$ & $\begin{array}{r}142.58, S D \\
10.45\end{array}$ & $18-61$ & $\begin{array}{r}35.07 \text { SD } \\
8.99\end{array}$ & $6-13$ & $\begin{array}{r}8.53 \mathrm{SD} \\
1.45\end{array}$ & $10-14$ & $\begin{array}{r}11.78 \mathrm{SD} \\
1.137\end{array}$ \\
\hline Girls & $\begin{array}{r}176 \\
(61.11)\end{array}$ & $123-167$ & $\begin{array}{r}144.62 \text { SD } \\
8.97\end{array}$ & $21-74$ & $\begin{array}{r}38.12 \text { SD } \\
10.29\end{array}$ & $5-13$ & $\begin{array}{r}8.13 \text { SD } \\
1.176\end{array}$ & $10-14$ & $\begin{array}{r}11.43 \text { SD } \\
.837\end{array}$ \\
\hline Total & 288 & $120-175$ & $\begin{array}{r}143.83 \text { SD } \\
9.64\end{array}$ & $18-74$ & $\begin{array}{r}36.93 \text { SD } \\
9.90\end{array}$ & $5-13$ & $\begin{array}{r}8.29 \mathrm{SD} \\
1.304\end{array}$ & $10-14$ & $\begin{array}{r}11.43 \mathrm{SD} \\
1.003\end{array}$ \\
\hline
\end{tabular}


Obesity and Its Risk Factors of among School Children

\begin{tabular}{|c|c|c|c|c|c|}
\hline Variables & Underweight & Normal weight & Overweight & Obese & $P$ value \\
\hline \multicolumn{6}{|l|}{ Sex } \\
\hline Boys & $30(26.78 \%)$ & $69(61.60 \%)$ & $9(8.03 \%)$ & $4(3.57 \%)$ & \\
\hline Girls & $22(12.5 \%)$ & $126(71.59 \%)$ & $16(9.09 \%)$ & $12(6.82 \%)$ & 0.017 \\
\hline Total & $52(18.05 \%)$ & $195(67.708 \%)$ & $25((8.68 \%)$ & $16(5.555 \%)$ & \\
\hline \multicolumn{6}{|l|}{ Economic class } \\
\hline Poor & $24(25 \%)$ & $70(72.916 \%)$ & $1(1.04 \%)$ & $1(1.04 \%)$ & \\
\hline Middle class & $26(18.43 \%)$ & $87(61.70 \%)$ & $15(10.0 \%)$ & $13(9.22 \%)$ & 0.001 \\
\hline Rich & $2(3.92 \%)$ & $38(74.51 \%)$ & $9(17.65 \%$ & $2(3.92 \%)$ & \\
\hline \multicolumn{6}{|c|}{ Duration of physical play } \\
\hline$<30 \mathrm{~min} /$ day & $10(18.18 \%)$ & $32(58.18 \%)$ & $10(18.18 \%)$ & $3(5.45 \%)$ & \\
\hline $30-60 \mathrm{~min} / \mathrm{d}$ & $12(11.11 \%)$ & $79(73.15 \%)$ & $9(8.33 \%)$ & $8(7.41 \%)$ & 0.001 \\
\hline$>60 \mathrm{~min} /$ day & $28((29.79 \%)$ & $61((64.89 \%)$ & $2(2.13 \%)$ & $3(3.19 \%)$ & \\
\hline \multicolumn{6}{|l|}{ Food habit } \\
\hline Fast food Yes & $48(19.75 \%)$ & $163(67.08 \%$ & $20(8.23 \%)$ & $12(4.94 \%)$ & 0.261 \\
\hline No & $4(8.89 \%)$ & $32(71.11 \%)$ & $5(11.11 \%)$ & $4(8.89 \%)$ & \\
\hline \multicolumn{6}{|l|}{ Television watch } \\
\hline Yes & $52(18.84 \%)$ & $185(67.03 \%)$ & $24(8.69 \%)$ & $15(5.43 \%)$ & 0.409 \\
\hline No & 0 & $10(83.33 \%$ & $1(8.33 \%)$ & $1(8.33 \%)$ & \\
\hline \multicolumn{6}{|l|}{ Video game } \\
\hline Yes & 27 (24.32\%) & $68(61.26 \%)$ & $7(6.31 \%)$ & $9(8.11 \%)$ & 0.004 \\
\hline No & $25(14.12 \%)$ & 127(71.75\%) & $18(10.17 \%)$ & $7(3.95 \%)$ & \\
\hline
\end{tabular}

Table 3. Regression analysis showing association of various factors with childhood obesity. Crude OR (B) Significance (P) OR (EXP B) 95\% Confidence Interval of OR (EXP B)

\begin{tabular}{|c|c|c|c|c|}
\hline Age & -.222 & .517 & .801 & $.410-1.567$ \\
\hline Female sex & .583 & .372 & 1.791 & $.498-6.440$ \\
\hline \multicolumn{5}{|l|}{ Economic condition } \\
\hline Middle class & 1.933 & .083 & 6.910 & $.799-61.272$ \\
\hline Rich & .638 & .634 & 1.893 & $.137-26.175$ \\
\hline \multicolumn{5}{|l|}{ Physical activity } \\
\hline No physical activity & .040 & .969 & 1.041 & $.140-7.713$ \\
\hline$<30$ minutes & .216 & .810 & 1.241 & $.213-7.222$ \\
\hline 30-60 minutes & .306 & .681 & 1.357 & $.317-5.818$ \\
\hline Watching television & -.973 & .427 & .378 & $.034-4.178$ \\
\hline Video game playing & .460 & .466 & 1.584 & $.460-5.449$ \\
\hline Computer game playing & .340 & .589 & 1.405 & $.409-4.826$ \\
\hline Sleeping duration & -.001 & .995 & .999 & $.659-1.513$ \\
\hline
\end{tabular}

However, in multivariate analysis sex was not found as an less in outdoor games and activities which may be a risk important associated factor for obesity and overweight. factor for childhood obesity. Average height and weight Shuhana et $\mathrm{al}^{13}$ also reported higher prevalence of of girls in this series were consistent with the report obesity and overweight among girls. But our findings by Shuhana. ${ }^{13}$ However, it differed from the report of differed from that of Mohsin et al. ${ }^{9}$ Girls are involved another study from India. ${ }^{8}$ 
Prevalence of obesity and overweight were found significantly lower $(P=0.001)$ among those who spent more time in physical exercise and outdoor games. Thus, more physical exercise and outdoor games were found as protective factors against obesity and overweight. Prevalence of obesity and overweight in our series was not found more in those who used to take fast food, which is consistent with the report from Beirut. ${ }^{14}$ In this study, prevalence of obesity was significantly higher among those who take part in video games $(P=0.004)$. Video games and television watching probably contribute to adopt a lifestyle that involves less physical activities. ${ }^{15}$ Television watching was not found to be significantly associated with obesity in our series which differed from the report from Iran. ${ }^{16}$ From the regression analysis higher economic condition and less physical activity were found as important predictors for childhood obesity and overweight.

\section{CONCLUSIONS}

Childhood obesity and overweight are disease of affluence. Higher economic condition and less physical activity are important predictors for childhood obesity and overweight.

\section{ACKNOWLEDGEMENTS}

We are grateful to teachers and students of department of Statistics, Shahjalal University of Science and Technology, Sylhet, Bangladesh for their immense support in analyzing and interpreting the data.

\section{REFERENCES}

1. Singh AS, Mulder C, Twisk JW, van Mechelen W, Chinapaw MJ. Tracking of childhood overweight in to adulthood: a systematic review of the literature. Obes Rev. 2008; 9: 474-488[DOI]

2. Bhuiyan MU, Zaman S, Ahmed T. Risk factors associated with overweight and obesity among urban school children and adolescents in Bangladesh: a case control study. BMC Pediatr. 2013;13(1):72-77[DOI]

3. De Onis M, Bloosner M, Borghi E. Global prevalence and trends of overweight and obesity among preschool children. Am J ClinNutr. 2019; 92:1257-1264 [DOI]

4. Lobstein T, Baur L, Uauy R. Obesity in Children and young people: a crisis in public health. Obes Rev. 2004; 5(Suppl1): 4-104 [DOI]
5. Wang $\mathrm{Y}$ and Lobstein T. Worldwide trends in childhood overweight and obesity. Int J Pediatric Obesity. 2006; 1: 11-25[DOI]

6. Langendiijk G, Welling S, Wyk M, Thomson SJ, McComb $\mathrm{J}$ and Chusilp K. The prevalnce of Childhood obesity in primary School Children in Urban KhonKaen, Northeast Thailand. Asia Pac J Clin Nutr. 2003; 12: 66-72[Full Text]

7. Warraich HJ, Javed F, Farazul-Haq M, Khawaja FB and Saleem S. Prevalence of obesity in School going children of Karachi 2009; PLoS ONE. 4(3): e4816. [DOI]

8. Ramchandran A, Snehlatha C, Vinita R, Thayyil M, Kumar $\mathrm{CK}$, Sheeba L et al. prevalence of overweight in urban Indian Adolescent School Children. Diabetic Res Clin Pract. 2002;57: 185-90[DOI]

9. Mohsin F, Tayyeb S, Baki A, Sarker S, Zabeen B, Begum T et al. Prevalence of obesity among affluent school children in Dhaka. Mymensingh Medical Journal. 2010; 19:549554[PMID]

10. Kuczmanski RJ, Oglen CL, Grummer Straw LM et al. CDC Growth Chart; United States. Washington DC. Centre for Disease Control and Prevention/ National Centre for Health Statistics. Advance Data. 2000; 314:1-28

11. Lemeshow S, Hosmer DW Jr, Klar J, Lwanga SK, editors. Chichester: John Wiley \& Sons; 1990. Adequacy of sample size in health studies. [Link]

12. Bulbul $T$, and Hoque M. Prevalence of childhood obesity and overweight in Bangladesh: Findings from a countrywide epidemiological study. BMC Pediatr. 2014; 14: 86-92[DOI]

13. Sultana S, Saleh F, Ali L. Childhood obesity in primary School children of middle and upper - middle income group in the capital city of Bangladesh. Food and Nutrition Science. 2015; 6: 1185-92

14. Jaber P, Sikias P, Khater-Menassa B, Boddoura R, Awada H. Overweight children in Beirut, prevalence estimates and characteristics. Child Care Health Dev. 2005;31:15965[DOI]

15. Singh AK, Maheswari A, Sharma N, Anand K. Lifestyle associated risk factors in adolescents. Indian J Pediatr. 2006; 73:901-906

16. Mozaffari H, Nabaei B. Obesity and related risk factors. Indian J Pediatr. 2007; 74:265-267 